\title{
Academia Internacional de Editores de Enfermagem
}

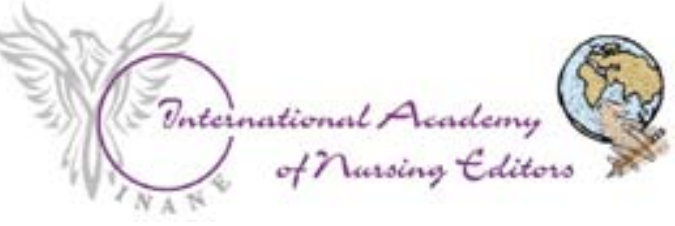

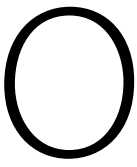
INANE mantém uma forma de organização do tipo não-governamental, mas com algumas diferenças, principalmente no modo de governo. Se organiza por uma teia de grupos de trabalho que são identificados por interesses, finalidades e necessidades. Os grupos de trabalho são abertos, os participantes entram e saem dos grupos de trabalho, conforme determinado pelo seu interesse e disponibilidade para aquela atividade.

A liderança é rotativa e flui bem como forma de aproximação do grupo. As decisões são tomadas por aqueles que voluntariamente assumem a responsabilidade por qualquer tarefa específica. Todas as decisões são tomadas em grupo, como a localização das futuras conferências anuais, em que algum voluntário lidera a tarefa, estas são realizadas desde 1983 e na sua maioria nos Estados Unidos, mas já ocorreram no Reino Unido, Canadá, África do Sul, Itália e Austrália. As grandes decisões são informadas por uma interação entre discussões abertas com a lista de e-mails, nas reuniões anuais durante a conferência, e as discussões subsequentes da lista de e-mails. Em última instância, as decisões finais são efetivadas por qualquer pessoa ou grupo de pessoas que aceitam a responsabilidade por uma tarefa específica. A cada ano uma pessoa que seja membro da organização se disponibiliza para liderar a agenda anual, inclusive para ser responsável pela conferência.

O site e uma lista de e-mails são geridos por um "Internet Services" de grupo de trabalho voluntário, os membros do grupo é que determinam responsabilidades específicas para as várias funções destes serviços importantes. O custo do nome de domínio do site e serviço de hospedagem é pago por doações voluntárias, o grupo publica um relatório anual dos custos envolvidos e como estes foram pagos. As necessidades financeiras do grupo são sustentadas por contribuições voluntárias individuais e de organizações. Para além da conferência anual, essas necessidades são mínimas.

\section{MISSÃO DO INANE}

O INANE é uma colaboração internacional - um coletivo de editores e editoras de enfermagem focado em atender a prática, pesquisa e educação às necessidades da profissão de enfermagem. A principal missão é promover as melhores práticas de publicação e altos padrões na publicação de periódicos de enfermagem, livros e base de dados da literatura.

Cada ano, em julho ou agosto o INANE realiza uma conferência internacional organizada por um membro voluntário. As conferências são realizadas pelo menos de três em três anos em um local diferente do que a América do Norte.

\section{COMO SE TORNAR MEMBRO DO INANE}

A "qualificação" fundamental para a adesão é a participação na produção e distribuição de literatura de enfermagem, e as atividades que mantêm e promovem elevados padrões profissionais na literatura. Exemplos dos tipos de papéis desempenhados pelos membros incluem editores, bibliotecários médicos / enfermeiros, indivíduos que monitoram a qualidade da literatura de enfermagem, revisores e os estudantes que anseiam por uma carreira de futuro que inclui a produção ou a distribuição de literatura de enfermagem. Qualquer pessoa de qualquer país que está envolvido na produção de literatura de enfermagem pode se juntar INANE sem custos.

As conferências anuais continuam a ser uma importante oportunidade de networking no local, mas mesmo se você não pode estar nas conferências, você pode estar na rede com outras pessoas usando todos os recursos da internet.

Use o formulário eletrônico para ativar a sua própria Home Page na lista Quem é Quem. Você pode usar o formulário a ser listado tanto no "Quem é Quem de Editores de Enfermagem" ou o "Quem é Quem - amigos e apoiadores" da lista. Você também pode utilizar este formulário para fazer uma mudança para sua lista atual. Quando preencher o formulário você terá a oportunidade de anexar uma foto de si mesmo, e da capa de sua revista. Os editores da Enfermagem em Foco estarão participando da Conferência de Montreal de 01 a 03 de agosto de 2012 no Painel: Broadening the Dialogue: What Makes a Global Conversation? Moderator: Marion Broome, Editor, Nursing Outlook.

Fazer parte do INANE é uma nova possibilidade de divulgação dos periódicos e as relações entre os membros são dinâmicas e mantém uma atualidade dos temas relacionados à editoração de revistas em todas as dimensões. 